Bond University

Research Repository

\title{
Determination of the concentration of major active anti-emetic constituents within commercial ginger food products and dietary supplements
}

Marx, Wolfgang; Isenring, Elisabeth A.; Lohning, Anna E.

Published in:

European Journal of Integrative Medicine

DOI:

10.1016/j.eujim.2017.02.001

Licence:

CC BY-NC-ND

Link to output in Bond University research repository.

Recommended citation(APA):

Marx, W., Isenring, E. A., \& Lohning, A. E. (2017). Determination of the concentration of major active anti-emetic constituents within commercial ginger food products and dietary supplements. European Journal of Integrative Medicine, 10, 19-24. https://doi.org/10.1016/j.eujim.2017.02.001

\section{General rights}

Copyright and moral rights for the publications made accessible in the public portal are retained by the authors and/or other copyright owners and it is a condition of accessing publications that users recognise and abide by the legal requirements associated with these rights.

For more information, or if you believe that this document breaches copyright, please contact the Bond University research repository coordinator 


\begin{abstract}
Introduction

Studies suggest that the bioactive compounds contained within the rhizome of ginger (Zingiber officinale) could exert a beneficial effect on the symptoms of several chronic conditions (e.g. diabetes, arthritis) and in the reduction of nausea. However, it is unknown if ginger supplements and food products contain sufficient quantities of the necessary active ingredients to achieve a therapeutic effect.
\end{abstract}

This study analyzed twenty commercially available ginger products including ginger dietary supplements, ginger spices (ground dried ginger), and ginger-containing drinks and food products and determined the concentration of [6]-, [8]- and [10]- gingerol and [6]- and [10]shogaol.

Methods

The samples were extracted prior to separation by Reversed Phase-High Performance Liquid Chromatography (RP-HPLC) and detected by ultraviolet (UV) spectrophotometry.

Results

Considerable variation between individual items within each food type was observed. Per gram, ginger supplements, particularly the standardized extracts, contained the greatest concentration of measured compounds (10.08 $\pm 7.92 \mathrm{mg}$, mean \pm standard deviation), while the concentration of compounds within spices $(9.29 \pm 6.73 \mathrm{mg})$, beverages $(1.77 \pm 1.06 \mathrm{mg})$, confectionery $(0.43 \pm 0.32$ $\mathrm{mg})$, and teas $(0.13 \pm 0.00 \mathrm{mg})$ was considerably lower. When the concentration of compounds were measured per standardized serve, four ginger confectionery and beverage products 
contained total gingerol and shogaol concentrations that were similar to the analyzed dietary supplement.

Conclusion

Of the twenty commercially available ginger products examined, those with the highest content of active, antiemetic constituents were the standardized ginger extracts and supplements although ginger spices also showed high levels of active constituents per serve. In addition, standard deviation reveals a large variation within each product type. 


\subsection{Introduction}

The rhizome of ginger (Zingiber officinale) contains many bioactive compounds. The gingerol class of compounds is the primary bioactive agent within the non-volatile, pungent component of ginger. Shogaols are the degradation product of gingerols. These are present in low concentrations in fresh ginger but increase when gingerols are exposed to heat, acid or other conditions which allow the alkene to form (an elimination product) (Bhattarai et al., 2001). The shogaols and gingerols are differentiated by the presence of either an aliphatic hydroxyl group, beta to the carbonyl (gingerols) or elimination of the hydroxyl group to form a double bond (shogaols) on the alpha carbon to the aliphatic carbonyl.

These compounds have been studied in clinical and pre-clinical studies for their effect on several chronic conditions such as diabetes and arthritis (Altman and Marcussen, 2001;

Khandouzi et al., 2015; Marx et al., 2013). The potentially beneficial effect of ginger on nausea has also been an area of significant research interest. A growing body of clinical trials has provided preliminary support for its use in multiple types of nausea such as motion sickness, morning sickness and chemotherapy-induced nausea and vomiting (Marx, W. et al., 2015; Thomson et al., 2014; Viljoen et al., 2014). Studies that have investigated the antioxidant, antiinflammatory, and chemo-preventive effect of individual compounds contained in ginger have reported different levels of activity depending on the chain length and presence of an alpha, betaunsaturated ketone group. For example, when several gingerol and shogaol compounds were compared, Dugasini et al. reported [6]-shogaol to be the most potent inhibitor of inflammation and reactive oxygen species production and [10]-gingerol to be the most potent gingerol. (Dugasani et al., 2010) 
Because of purported medicinal effects, ginger products are often used by the general population as complementary medicines and are sometimes recommended by healthcare professionals as adjuvants to standard therapy (Forster et al., 2006; Holst et al., 2009; Molassiotis et al., 2011). However, there are currently few studies that have investigated the concentration of active compounds in a wide-variety of commercially available products, and thereby providing a reliable guide to appropriate use of these products (Schwertner et al., 2006; Schwertner and Rios, 2007). Due to the increasing public use of complementary treatments such as dietary supplements, information regarding the potency of available ginger preparations will also be of interest to healthcare professionals seeking these products for their adjuvant medicinal properties to determine their potential to produce side effects and interactions. Due to the differing biological activity of the gingerol and shogaol compounds, it is also prudent to measure the concentration of each of these individual compounds within commonly consumed ginger products.

The aim of this study was to determine the concentration of the primary bioactive compounds within an expanded range of commercially available ginger products, including dietary supplements and ginger-containing drinks and food products using Reverse Phase-High Performance Liquid Chromatography (RP-HPLC). Using the results of this analysis, the clinical and research implications of the therapeutic use of ginger products will be discussed.

\subsection{Methods}

\subsection{Chemicals and Materials}

HPLC-grade water, methanol, ethyl acetate, and acetonitrile were purchased from ThermoFisher (Massachusetts, USA) and Sigma Aldrich (Missouri, USA). [6]-, [8]- and [10]- gingerol and [6]- 
and [10]-shogaol standards were purchased from Chromadex (Irvine, CA, U.S.A). Ginger products were purchased from one local supermarket (Gold Coast, Australia) and one online store (based in New Zealand) in April, 2014. In addition, one supplement was supplied by the respective manufacturer for use in this study. In total, 20 products were purchased, including dietary supplements, beverages, spices (ground ginger), teas, and confectionery.

\subsection{Sample preparation}

Due to the variety of types of ginger products analyzed, two extraction protocols were required. All samples were prepared in triplicate. Percentage yield was determined by conducting each extraction protocol with a $0.08 \mathrm{mg} / \mathrm{mL}$ standard mix.

\subsection{Ethyl acetate extraction}

In order to analyze the ginger supplements, biscuit, and spices, ethyl acetate $(10 \mathrm{~mL})$ was added to 500mg samples of spices, pierced supplements or crushed biscuit.

Samples were vortexed then sonicated for 30 minutes using a CamLab TransSonic T310 sonicator. Samples were centrifuged (20 minutes at 2500rpm and 25 degrees Celsius) using a Beckman Coulter Allegra X-15R centrifuge. The supernatant was subjected to second pass extraction using an additional ethyl acetate $(10 \mathrm{~mL})$. The supernatants of both extractions from each product were combined and evaporated to dryness. The samples were reconstituted in methanol $(1.5 \mathrm{~mL})$ and stored at $4^{\circ} \mathrm{C}$.

Serving sizes for the supplements and biscuit were in accordance with suggested serving sizes by the manufacturer. The serving size for the spices was set at 0.2 gram.

\subsection{Liquid/liquid extraction}


Beverage samples (50mL, degassed) and confectionery samples (500mg) were diluted in HPLC water $(15 \mathrm{~mL})$. For the tea products, three tea bags were infused in HPLC-grade water $(50 \mathrm{~mL}$, room temperature) for three minutes. All samples were left overnight and then extracted in ethyl acetate $(10 \mathrm{~mL})$. A second pass extraction was conducted. The supernatants of both extractions from each product were combined and evaporated to dryness. The samples were reconstituted in methanol $(1.5 \mathrm{~mL})$ and stored at $4^{\circ} \mathrm{C}$.

The serving size of the beverages was set at $250 \mathrm{~mL}$ and confectionery serving size was defined as $5 \mathrm{~g}$, as this was found to be the approximate weight of a single piece of confectionery.

\subsection{Standard preparation}

Stock solutions $(10 \mathrm{~mL})$ of each standard were prepared from the $5 \mathrm{mg}$ material supplied by the manufacturer Chromadex (Irvine, CA, U.S.A). A dilution series of the standard mix were prepared as needed between $0.50 \mathrm{ug} / \mathrm{mL}$ to $200 \mathrm{ug} / \mathrm{mL}$. Working standards were prepared in the range of 0.0005 to $0.2 \mathrm{mg} / \mathrm{mL}$ and stored at $4^{\circ} \mathrm{C}$.

\subsection{HPLC analysis}

Ginger samples were separated on a Waters Alliance e-2695 Separations System RP-HPLC and detected with a 2489 Dual-Beam UV detector. A 150x4.6mm C-18 reversed phase column (Luna C18 5 $\mu \mathrm{M}$; Phenomenex, USA) was fitted with a guard column.

The mobile phase consisted of HPLC-grade water (A) and acetonitrile (B) at starting conditions of $90 \%$ A. Analytical conditions included an injection volume of $10 \mu \mathrm{L}$, flow rate of $1.5 \mathrm{~mL}$ per minute and a column temperature of $27^{\circ} \mathrm{C}$. A binary gradient elution system was applied as follows: $0.0-1.85 \mathrm{~min}, 10-50 \% \mathrm{~B} ; 1.86-7.88 \mathrm{~min}, 55 \% \mathrm{~B} ; 7.89-11.59 \mathrm{~min}, 66 \% \mathrm{~B} ; 12-17.6$ 
$\min , 100 \%$ B. $17.61-25 \min 10 \%$ B. The UV absorbance was measured at $205 \mathrm{~nm}$. Peak identification was based on the retention time of the standards.

\subsection{Results}

Calibration curves for [6]-gingerol, [6]-shogaol, [8]-gingerol, [10]-shogaol, and [10]-gingerol were linear between 0.5 to $200.0 \mathrm{ng} / \mathrm{mL}$ (correlation coefficient for each compound were $\geq 0.9992)$.

Sample chromatograms for each of the product categories are set out in Supplemental Information 1.

As expected the elution order correlates with the lipophilicity of each compound, that is, [6]gingerol, [8]-gingerol, [6]-shogaol, [10]-gingerol, [10]-shogaol.

The limit of detection (LoD) was determined using the standard deviation of each component calibration curve and slope. The $\mathrm{LoD}$ was calculated as 3.3 times the ratio of standard deviation to slope for each component while the limit of quantitation (LoQ) was calculated as $10 \mathrm{x}$ the ratio of standard deviation to slope for each component (Table 1).

The mean concentration of [6]-gingerol, [6]-shogaol, [8]-gingerol, [10]-gingerol and [10]shogaol of all ginger products are tabulated per gram (Table 2) and per serving (Table 3) after they had been adjusted by the percentage yield as determined by the validation protocol.

In all samples, [6]-gingerol was consistently detected in the highest concentration when compared to all other compounds investigated while [8]-gingerol and [10]-shogaol were found in the lowest concentration. In descending order, the total concentration of each compound from all analyzed products was [6]-gingerol (67.42mg), [6]-shogaol (20.18mg), [10]-gingerol (15.52mg), 
[10]-shogaol (7.78mg), [8]-gingerol (7.58mg). This order of [6]-gingerol, [6]-shogaol, and [10]gingerol remained consistent for each product; however, some products contained slightly higher concentrations of [8]-gingerol than [10]-shogaol.

Figure 1 Total mean gingerol and shogaol content of ginger products per gram by group

The concentration of analyzed compounds, particularly within the beverages, varied considerably

(Figure 1). When compared per gram, with one exception, ginger supplements (particularly

those that were made from standardized extracts) contained the largest concentration of analyzed compounds when compared to all other ginger products. Ginger spices also tended to contain a large concentration of compounds per gram while the ginger biscuit contained the lowest amount. When the concentration of each product was compared per serve, standardized extracts still contained some of the largest concentration of compounds (Figure 2). Products from other categories (i.e. beverages and confectionery) contained concentrations of compounds similar to the standardized extracts.

Figure 2 Total mean gingerol and shogaol content of ginger products per serve by group

\subsection{Discussion}

In this study, the concentration of the principle gingerol and shogaol compounds was analyzed in 20 commercially available ginger products. The results of the current study expand on previous studies by increasing the range and type of products analyzed and by including an additional compound, [10]-shogaol, in the analysis. [10]-shogaol has not been extensively studied; however, in vitro research suggests that it exerts anti-inflammatory properties and might aid wound healing (Chen et al., 2012; van Breemen et al., 2011). Hence, quantification of this compound in various ginger products can assist in future research studies. 
In line with previous studies, the amount of each compound was relatively consistent across all products with [6]-gingerol and its degradation product, [6]-shogaol detected in the greatest concentrations and [8]-gingerol and [10]-shogaol in the smallest concentrations (Schwertner and Rios, 2007; Shao et al., 2010). The greater concentration of [6]-gingerol is to be expected as [6]gingerol is the primary non-volatile pungent compound within the oleoresin of ginger.

This analysis also demonstrated a substantial variation in bioactive compounds between products. Per gram, ginger supplements, particularly the standardized extracts, contained the greatest concentration of measured compounds, while the concentration of compounds within other product categories varied considerably. These findings are similar to the results of previously published analyses by other groups (Schwertner et al., 2006; Schwertner and Rios, 2007; Shao et al., 2010).

The low concentration of active compounds contained in the analyzed tea products is in contrast to previous research which reported tea products to be similar in concentration to some dietary supplements and spices (Schwertner and Rios, 2007; Shao et al., 2010). However, we chose to measure the concentrations of active ingredients in brewed tea in order to better reflect the amount of active ingredients likely to be ingested with tea consumption, as opposed to previous studies which measured the concentration of active ingredients in the tea bag before brewing. Because gingerol compounds transform into shogaols when exposed to heat, our method provides a more accurate determination of the active ingredients consumed under normal conditions.

Previous studies reported that the total concentration of active components within commercially available dietary supplements varied considerably from the manufacturers' claims (Harkey et al., 2001; Heptinstall et al., 1992). In contrast, we found that the concentrations of gingerols and 
shogaols in the three standardized extracts included in this analysis were consistent with those published by the manufacturers.

When analyzed in terms of the approximate concentration that would be consumed in one recommended serve of each product, there were dietary supplements as well as some confectionery and beverage products, that contained large concentrations of the analyzed compounds. Ginger ales and confectionery are often recommended by health professionals to treat nausea. Currently, the smallest effective dose of ginger as well as the optimal form of ginger has not been elucidated and is an area that requires continued research to inform clinical practice. However, these results demonstrate that it is feasible to achieve an intake of the principle active compounds of ginger by consuming certain commercially available food products that is comparable to most dietary supplements analyzed in this study as well as effective doses used in previous clinical trials. For example, a large $\mathrm{RCT}(\mathrm{N}=576)$ reported that two dosages of a standardized ginger extract, 0.5 and $1 \mathrm{~g} /$ day, were effective in reducing chemotherapy-induced nausea and vomiting (Ryan et al., 2012). The effective daily dose of gingerol and shogaol for each dosage was $17 \mathrm{mg}$ and $34 \mathrm{mg}$, respectively. In our analysis, four confectionery and beverage products contained a total gingerol and shogaol concentration similar to the dosage used in previous studies and the dietary supplements included in the current analysis (Ryan et al., 2012). Therefore, these results also suggest that it is indeed feasible to attain equivalent amounts of gingerol and shogaols used in previous clinical trials via dietary intake (Ryan et al., 2012). This demonstrates the need for the consumption of ginger products to be monitored during future clinical trials investigating ginger because the consumption of additional ginger products is likely to influence the effective total intake of ginger compounds. Furthermore, previous studies have demonstrated a potential ceiling effect with higher doses $(2 \mathrm{~g})$ 
of ginger supplementation resulting in less or no control of symptoms compared to lower doses (Marx et al., 2013). Thus, the consumption of additional ginger products could potentially increase the total consumption of active compounds in excess of a therapeutic dosage.

In addition, as previously noted by our group as well as other authors, the lack of analysis of ginger preparations and the lack of standardized extracts used in clinical trials could be responsible for the sometimes conflicting results reported due to the variability in active compounds (Marx, Wolfgang et al., 2015; Marx et al., 2013; Schwertner and Rios, 2007). The results of this study support this concern as there was a large difference in the detected concentration of each investigated product, including the ginger supplements. Hence, the measurement of the concentration of the active compounds within ginger products as well as the use of standardized extracts is indicated in future trials.

It should be noted that ginger contains a wide variety of bioactive compounds that have potentially beneficial properties (Chrubasik et al., 2005). Therefore, while this study was able to determine the concentration of an expanded range of these principle compounds compared to previous studies, other potentially important ginger compounds were not able to be analyzed due to the lack of commercial standards. Investigation of the concentrations of other compounds such as zingibain and dehydroshogaols in commercial products is recommended in future studies as these compounds have also demonstrated biological activity relevant to chronic conditions (Chrubasik et al., 2005). A second limitation of this study is that some of the samples used were purchased commercially from nearby stores. The concentration of compounds could have been influenced by factors such as storage conditions; therefore, the results of this analysis might not be representative of the product when stored in different conditions. There is also the possibility that there was a variation in the concentration of analyzed compounds between different batches 
of the same product, particularly if different batches are sourced from multiple locations. This study analyzed a single sample of each product and so future trials may benefit from analyzing multiple batches of the same product. Finally, due to the use of ethyl-acetate to extract the active compounds, our study provides limited data on the bioaccessability of the active compounds. However, rather than to compare the bioaccessibilty of target analytes, the current study was designed to measure and compare the total composition of gingerols and shogaols in the included products. The bioaccessibilty of these compounds is an area of necessary research and future studies that resemble the human digestive process (e.g. by using an aqueous extraction) are required to improve the current literature.

In summary, using an expanded range of commercial ginger products, the inclusion of an additional active compound, and a protocol designed to reflect the concentration of active compounds likely to be consumed, the results and discussion of this study provide novel clinical and research recommendations regarding the therapeutic use of ginger products.

\subsection{Conclusion}

An analysis of 20 commercially available ginger products demonstrated wide variation in the total amount of gingerols and shogaols within different ginger products, with standardized ginger extracts and spices containing the largest concentration of compounds. Biscuits and teas contained the least concentrations of the relevant compounds. When calculated by serving, certain beverages and confectionery contained similar or greater concentrations of the analyzed compounds to the ginger supplements; hence, future clinical trials investigating ginger formulations should ensure that the consumption of other ginger products is monitored so as to not confound the study results. In addition, the inconsistent concentration of active compounds 
within ginger supplements demonstrates the need for standardized extracts and the use of RPHPLC in clinical trials to ensure sufficiently potent interventions. 


\section{ACKNOWLEDGMENTS}

We would like to thank Helsinn Integrative Care for supplying one of the ginger extracts for this study. 


\section{References}

1. Altman, R.D., Marcussen, K.C., 2001. Effects of a ginger extract on knee pain in patients with osteoarthritis. Arthritis Rheum 44(11), 2531-2538.

2. Bhattarai, S., Tran, V.H., Duke, C.C., 2001. The stability of gingerol and shogaol in aqueous solutions. J Pharm Sci 90(10), 1658-1664.

3. Chen, C.-Y., Cheng, K.-C., Chang, A.Y., Lin, Y.-T., Hseu, Y.-C., Wang, H.-M., 2012. 10-Shogaol, an Antioxidant from Zingiber officinale for Skin Cell Proliferation and Migration Enhancer. International Journal of Molecular Sciences 13(2), 1762-1777.

4. Chrubasik, S., Pittler, M., Roufogalis, B., 2005. Zingiberis rhizoma: a comprehensive review on the ginger effect and efficacy profiles. Phytomedicine 12, $684-701$.

5. Dugasani, S., Pichika, M.R., Nadarajah, V.D., Balijepalli, M.K., Tandra, S., Korlakunta, J.N., 2010. Comparative antioxidant and anti-inflammatory effects of [6]-gingerol, [8]gingerol, [10]-gingerol and [6]-shogaol. J Ethnopharmacol 127(2), 515-520.

6. Forster, D., Denning, A., Wills, G., Bolger, M., McCarthy, E., 2006. Herbal medicine use during pregnancy in a group of Australian women. BMC Pregnancy Childbirth 9, 21.

7. Harkey, M.R., Henderson, G.L., Gershwin, M.E., Stern, J.S., Hackman, R.M., 2001. Variability in commercial ginseng products: an analysis of 25 preparations. Am J Clin Nutr 73(6), 1101-1106.

8. Heptinstall, S., Awang, D.V., Dawson, B.A., Kindack, D., Knight, D.W., May, J., 1992. Parthenolide content and bioactivity of feverfew (Tanacetum parthenium (L.) SchultzBip.). Estimation of commercial and authenticated feverfew products. The Journal of pharmacy and pharmacology 44(5), 391-395.

9. Holst, L., Wright, D., Haavik, S., Nordeng, H., 2009. The use and the user of herbal remedies during pregnancy. J Altern Complement Med 15(7), 787 - 792.

10. Khandouzi, N., Shidfar, F., Rajab, A., Rahideh, T., Hosseini, P., Mir Taheri, M., 2015. The effects of ginger on fasting blood sugar, hemoglobin a1c, apolipoprotein B, apolipoprotein a-I and malondialdehyde in type 2 diabetic patients. Iran J Pharm Res 14(1), 131-140.

11. Marx, W., Kiss, N., Isenring, L., 2015. Is ginger beneficial for nausea and vomiting? An update of the literature. Current Opinion in Supportive and Palliative Care 9(2), 189-195.

12. Marx, W., Ried, K., McCarthy, A.L., Vitetta, L., Sali, A., McKavanagh, D., Isenring, E., 2015. Ginger-Mechanism of Action in Chemotherapy-induced Nausea and Vomiting: A Review. Crit Rev Food Sci Nutr, 0.

13. Marx, W.M., Teleni, L., McCarthy, A.L., Vitetta, L., McKavanagh, D., Thomson, D., Isenring, E., 2013. Ginger (Zingiber officinale) and chemotherapy-induced nausea and vomiting: a systematic literature review. Nutr. Rev. 71(4), 245-254.

14. Molassiotis, A., Brearley, S.G., Stamataki, Z., 2011. Use of antiemetics in the management of chemotherapy-related nausea and vomiting in current UK practice. Support Care Cancer 19(7), 949-956.

15. Ryan, J.L., Heckler, C.E., Roscoe, J.A., Dakhil, S.R., Kirshner, J., Flynn, P.J., Hickok, J.T., Morrow, G.R., 2012. Ginger (Zingiber officinale) reduces acute chemotherapyinduced nausea: a URCC CCOP study of 576 patients. Support Care Cancer 20(7), 14791489. 
16. Schwertner, H., Rios, D., Pascoe, J., 2006. Variation in concentration and labeling of ginger root dietary supplements. Obstet Gynecol 107, 1337 - 1343.

17. Schwertner, H.A., Rios, D.C., 2007. High-performance liquid chromatographic analysis of 6-gingerol, 8-gingerol, 10-gingerol, and 6-shogaol in ginger-containing dietary supplements, spices, teas, and beverages. J Chromatogr B Analyt Technol Biomed Life Sci 856(1-2), 41-47.

18. Shao, X., Lv, L., Parks, T., Wu, H., Ho, C.T., Sang, S., 2010. Quantitative analysis of ginger components in commercial products using liquid chromatography with electrochemical array detection. J Agric Food Chem 58(24), 12608-12614.

19. Thomson, M., Corbin, R., Leung, L., 2014. Effects of ginger for nausea and vomiting in early pregnancy: a meta-analysis. Journal of the American Board of Family Medicine : JABFM 27(1), 115-122.

20. van Breemen, R.B., Tao, Y., Li, W., 2011. Cyclooxygenase-2 inhibitors in ginger (Zingiber officinale). Fitoterapia 82(1), 38-43.

21. Viljoen, E., Visser, J., Koen, N., Musekiwa, A., 2014. A systematic review and metaanalysis of the effect and safety of ginger in the treatment of pregnancy-associated nausea and vomiting. Nutr J 13, 20. 


\section{TABLES}

\begin{tabular}{|l|c|c|c|}
\hline Ginger component & $\begin{array}{c}\text { Coefficient of determination } \\
\left(\mathrm{R}^{2}\right)\end{array}$ & Limit of & Limit of \\
& & & Quantitation \\
& & & \\
\hline$[6]-$ Lingerol & & \\
\hline$[8]-$ Gingerol & 0.9995 & $6.05 \times 10^{-3} \mathrm{ug} / \mathrm{mL}$ & $21.4 \mathrm{ug} / \mathrm{mL}$ \\
\hline$[10]-$ Gingerol & 0.9996 & $8.68 \times 10^{-3} \mathrm{ug} / \mathrm{mL}$ & $20.5 \mathrm{ug} / \mathrm{mL}$ \\
\hline [6]-Shogaol & 0.9994 & $7.71 \times 10^{-3} \mathrm{ug} / \mathrm{mL}$ & $26.2 \mathrm{ug} / \mathrm{mL}$ \\
\hline$[10]-$ Shogaol & 0.9993 & $8.47 \times 10^{-3} \mathrm{ug} / \mathrm{mL}$ & $25.7 \mathrm{ug} / \mathrm{mL}$ \\
\hline
\end{tabular}

Table 1. Correlation coefficient and Limits of Detection/Quantitation for each component 
Table 2. Mean \pm standard deviation concentration in analyzed products per gram.

\begin{tabular}{|c|c|c|c|c|c|c|}
\hline Supplements & $\begin{array}{l}\text { Total } \\
\text { (mg/caps } \\
\text { ule) }\end{array}$ & $\begin{array}{l}6 \mathrm{G} \\
(\mathrm{mg} / \mathrm{L})\end{array}$ & $\begin{array}{l}8 G \\
(\mathrm{mg} / \mathrm{L})\end{array}$ & $\begin{array}{l}10 \mathrm{G} \\
(\mathrm{mg} / \mathrm{L})\end{array}$ & $\begin{array}{l}6 \mathrm{~S} \\
(\mathrm{mg} / \mathrm{L})\end{array}$ & $\begin{array}{l}10 \mathrm{~S} \\
(\mathrm{mg} / \mathrm{L})\end{array}$ \\
\hline $\begin{array}{l}\text { Nature's Own Travel } \\
\text { Well } 1000\end{array}$ & 0.66 & $0.47 \pm 0.02$ & $0.00 \pm 0.00$ & $0.02 \pm 0.01$ & $0.14 \pm 0.01$ & $0.03 \pm 0.00$ \\
\hline $\begin{array}{l}\text { Lifestream Ginger } \\
\text { capsules }\end{array}$ & 7.44 & $4.59 \pm 0.73$ & $0.35 \pm 0.20$ & $0.88 \pm 0.15$ & $1.22 \pm 0.21$ & $0.38 \pm 0.07$ \\
\hline $\begin{array}{l}\text { Nature's Sunshine } \\
\text { Ginger }\end{array}$ & 7.02 & $2.32 \pm 0.03$ & $0.43 \pm 0.02$ & $0.89 \pm 0.02$ & $2.20 \pm 0.05$ & $1.17 \pm 0.04$ \\
\hline $\begin{array}{l}\text { BlueBonnet Ginger root } \\
\text { extract }\end{array}$ & 23.57 & $\begin{array}{l}12.76 \pm 0.0 \\
1\end{array}$ & $1.74 \pm 0.01$ & $2.89 \pm 0.01$ & $4.63 \pm 0.01$ & $1.55 \pm 0.01$ \\
\hline $\begin{array}{l}\text { Blackmores Travel Calm } \\
\text { Ginger }\end{array}$ & 7.36 & $4.35 \pm 0.15$ & $0.61 \pm 0.02$ & $1.00 \pm 0.04$ & $1.03 \pm 0.03$ & $0.37 \pm 0.02$ \\
\hline $\begin{array}{l}\text { Helsinn Integrative Care } \\
\text { Ginpax 40mg soft gel } \\
\text { capsule }\end{array}$ & 14.46 & $\begin{array}{l}11.08 \pm 1.4 \\
9\end{array}$ & $0.14 \pm 0.04$ & $2.77 \pm 0.44$ & $0.02 \pm 0.01$ & $0.44 \pm 0.05$ \\
\hline Spices & $\begin{array}{l}\text { Total } \\
(\mathrm{mg} / \mathrm{g})\end{array}$ & $\begin{array}{l}6 \mathrm{G} \\
(\mathrm{mg} / \mathrm{L})\end{array}$ & $\begin{array}{l}8 G \\
(\mathrm{mg} / \mathrm{L})\end{array}$ & $\begin{array}{l}10 G \\
(\mathrm{mg} / \mathrm{L})\end{array}$ & $\begin{array}{l}6 \mathrm{~S} \\
(\mathrm{mg} / \mathrm{L})\end{array}$ & $\begin{array}{l}10 \mathrm{~S} \\
(\mathrm{mg} / \mathrm{L})\end{array}$ \\
\hline $\begin{array}{l}\text { Woolworth's Ginger } \\
\text { Spice Powder }\end{array}$ & 13.42 & $5.64 \pm 0.02$ & $1.34 \pm 0.00$ & $3.11 \pm 0$ & $2.13 \pm 0.00$ & $1.19 \pm 0.0$ \\
\hline $\begin{array}{l}\text { Coles Ginger Spice } \\
\text { Powder }\end{array}$ & 12.93 & $5.50 \pm 0.17$ & $1.21 \pm 0.04$ & $3.12 \pm 0.1$ & $2.01 \pm 0.0$ & $1.09 \pm 0.04$ \\
\hline
\end{tabular}




\begin{tabular}{|c|c|c|c|c|c|c|}
\hline $\begin{array}{l}\text { Hertz Ginger Spice } \\
\text { Powder }\end{array}$ & 1.53 & $0.88 \pm 0.13$ & $0.14 \pm 0.02$ & $0.22 \pm 0$ & $0.21 \pm 0.03$ & $0.08 \pm 0.01$ \\
\hline Beverages & $\begin{array}{l}\text { Total } \\
(\mathrm{mg} / \mathrm{L})\end{array}$ & $\begin{array}{l}6 \mathrm{G} \\
(\mathrm{mg} / \mathrm{L})\end{array}$ & $\begin{array}{l}8 \mathrm{G} \\
(\mathrm{mg} / \mathrm{L})\end{array}$ & $\begin{array}{l}10 \mathrm{G} \\
(\mathrm{mg} / \mathrm{L})\end{array}$ & $\begin{array}{l}6 \mathrm{~S} \\
(\mathrm{mg} / \mathrm{L})\end{array}$ & $\begin{array}{l}10 \mathrm{~S} \\
(\mathrm{mg} / \mathrm{L})\end{array}$ \\
\hline Coles Dry Ginger Ale & 1.94 & $1.58 \pm 0.66$ & $0.04 \pm 0$ & $0.18 \pm 0.1$ & $0.10 \pm 0.08$ & $0.04 \pm 0.04$ \\
\hline $\begin{array}{l}\text { Bundaberg Diet Ginger } \\
\text { Beer }\end{array}$ & 0.61 & $0.53 \pm 0.02$ & $0.02 \pm 0.00$ & $0.00 \pm 0$ & $0.05 \pm 0.0$ & $0.00 \pm 0.0$ \\
\hline Saxby Dry Ginger Beer & 2.20 & $1.85 \pm 0.21$ & $0.04 \pm 0.03$ & $0.14 \pm 0$ & $0.11 \pm 0.01$ & $0.06 \pm 0.01$ \\
\hline Cascade Ginger Beer & 3.23 & $2.86 \pm 0.41$ & $0.07 \pm 0.04$ & $0.13 \pm 0$ & $0.12 \pm 0.01$ & $0.04 \pm 0.0$ \\
\hline Tiger Ginger Beer & 0.86 & $0.50 \pm 0.66$ & $0.04 \pm 0.03$ & $0.18 \pm 0.1$ & $0.10 \pm 0.08$ & $0.04 \pm 0.04$ \\
\hline Confectionary & $\begin{array}{l}\text { Total } \\
(\mathrm{mg} / \mathrm{L})\end{array}$ & $\begin{array}{l}6 \mathrm{G} \\
(\mathrm{mg} / \mathrm{L})\end{array}$ & $\begin{array}{l}8 \mathrm{G} \\
(\mathrm{mg} / \mathrm{L})\end{array}$ & $\begin{array}{l}10 \mathrm{G} \\
(\mathrm{mg} / \mathrm{L})\end{array}$ & $\begin{array}{l}6 \mathrm{~S} \\
(\mathrm{mg} / \mathrm{L})\end{array}$ & $\begin{array}{l}10 \mathrm{~S} \\
(\mathrm{mg} / \mathrm{L})\end{array}$ \\
\hline Gin Gins Candies & 0.68 & $0.60 \pm 0.05$ & $0.02 \pm 0.00$ & $0.02 \pm 0$ & $0.03 \pm 0.0$ & $0.01 \pm 0.0$ \\
\hline $\begin{array}{l}\text { Buderim Crystallised } \\
\text { Ginger }\end{array}$ & 0.70 & $0.63 \pm 0.06$ & $0.00 \pm 0.00$ & $0.02 \pm 0$ & $0.04 \pm 0.0$ & $0.00 \pm 0.0$ \\
\hline Buderim Ginger bears & 0.34 & $0.32 \pm 0.02$ & $0.01 \pm 0.00$ & $0.00 \pm 0$ & $0.01 \pm 0.00$ & $0.00 \pm 0$ \\
\hline $\begin{array}{l}\text { Arnotts GingerNut } \\
\text { Biscuits }\end{array}$ & 0.02 & $0.02 \pm 0.00$ & $0.00 \pm 0.00$ & $0.00 \pm 0$ & $0.00 \pm 0$ & $0.00 \pm 0$ \\
\hline Teas & $\begin{array}{l}\text { Total } \\
(\mathrm{mg} / \mathrm{L})\end{array}$ & $\begin{array}{l}6 \mathrm{G} \\
(\mathrm{mg} / \mathrm{L})\end{array}$ & $\begin{array}{l}8 \mathrm{G} \\
(\mathrm{mg} / \mathrm{L})\end{array}$ & $\begin{array}{l}10 \mathrm{G} \\
(\mathrm{mg} / \mathrm{L})\end{array}$ & $\begin{array}{l}6 \mathrm{~S} \\
(\mathrm{mg} / \mathrm{L})\end{array}$ & $\begin{array}{l}10 S \\
(\mathrm{mg} / \mathrm{L})\end{array}$ \\
\hline $\begin{array}{l}\text { Twinings Ginger \& } \\
\text { Lemon Tea }\end{array}$ & 0.13 & $0.13 \pm 0.00$ & $0.00 \pm 0.00$ & $0.00 \pm 0$ & $0.00 \pm 0$ & $0.00 \pm 0$ \\
\hline $\begin{array}{l}\text { Nerada Ginger \& Lemon } \\
\text { Tea }\end{array}$ & 0.13 & $0.13 \pm 0.01$ & $0.00 \pm 0.00$ & $0.00 \pm 0$ & $0.00 \pm 0$ & $0.00 \pm 0$ \\
\hline
\end{tabular}

*6G=[6]-gingerol, 8G =[8]-gingerol, 6S=[6]-shogaol, 10G=[10]-gingerol, 10S=[10]-shogaol. 
Table 3. Mean \pm standard deviation concentration of [6]-gingerol, [6]-shogaol, [8]-gingerol, [10]-gingerol and [10]-shogaol in analyzed products per serving size.

\begin{tabular}{|c|c|c|c|c|c|c|c|}
\hline Supplements & \begin{tabular}{|l} 
Estimate \\
d serving \\
size (g)
\end{tabular} & $\begin{array}{l}\text { Total } \\
\text { (Per } \\
\text { serving } \\
\text { ) }\end{array}$ & $\begin{array}{c}\text { 6G } \\
(\text { Per } \\
\text { serving) }\end{array}$ & $\begin{array}{c}\text { 8G } \\
\text { (Per } \\
\text { serving) }\end{array}$ & $\begin{array}{c}\text { 10G } \\
(\text { Per } \\
\text { serving) }\end{array}$ & $\begin{array}{c}6 \mathrm{~S} \\
(\mathrm{Per} \\
\text { serving) }\end{array}$ & $\begin{array}{c}\text { 10S } \\
(\text { Per } \\
\text { serving) }\end{array}$ \\
\hline $\begin{array}{l}\text { Nature's Own } \\
\text { Travel Well } 1000\end{array}$ & $0.85 \mathrm{~g}$ & 1.68 & $1.19 \pm 0.05$ & $0.00 \pm 0$ & $\begin{array}{l}0.36 \pm 0.0 \\
3\end{array}$ & $\begin{array}{l}0.05 \pm 0.02 \\
6\end{array}$ & $0.08 \pm 0$ \\
\hline $\begin{array}{l}\text { Lifestream } \\
\text { Ginger capsules }\end{array}$ & $0.66 \mathrm{~g}$ & 18.92 & $\begin{array}{l}11.68 \pm 1.8 \\
6\end{array}$ & $\begin{array}{l}0.90 \pm 0.5 \\
1\end{array}$ & $\begin{array}{l}3.11 \pm 0.5 \\
3\end{array}$ & $\begin{array}{l}2.25 \pm 0.38 \\
1\end{array}$ & $\begin{array}{l}0.98 \pm 0.1 \\
7\end{array}$ \\
\hline $\begin{array}{l}\text { Nature's } \\
\text { Sunshine Ginger }\end{array}$ & $0.60 \mathrm{~g}$ & 12.58 & $4.16 \pm 0.05$ & $\begin{array}{l}0.76 \pm 0.0 \\
3\end{array}$ & $3.95 \pm 0.1$ & $\begin{array}{l}1.60 \pm 0.03 \\
7\end{array}$ & $\begin{array}{l}2.10 \pm 0.0 \\
7\end{array}$ \\
\hline $\begin{array}{l}\text { BlueBonnet } \\
\text { Ginger root } \\
\text { extract }\end{array}$ & $0.52 \mathrm{~g}$ & 36.43 & $\begin{array}{l}19.72 \pm 0.0 \\
2\end{array}$ & $\begin{array}{l}2.69 \pm 0.0 \\
2\end{array}$ & $\begin{array}{l}7.15 \pm 0.0 \\
2\end{array}$ & $\begin{array}{l}4.46 \pm 0.01 \\
6\end{array}$ & $\begin{array}{l}2.39 \pm 0.0 \\
2\end{array}$ \\
\hline $\begin{array}{l}\text { Blackmores } \\
\text { Travel Calm } \\
\text { Ginger }\end{array}$ & $0.51 \mathrm{~g}$ & 11.16 & $6.60 \pm 0.22$ & $\begin{array}{l}0.92 \pm 0.0 \\
3\end{array}$ & $\begin{array}{l}1.56 \pm 0.0 \\
5\end{array}$ & $\begin{array}{l}1.51 \pm 0.05 \\
5\end{array}$ & $\begin{array}{l}0.57 \pm 0.0 \\
3\end{array}$ \\
\hline $\begin{array}{l}\text { Helsinn } \\
\text { Integrative Care } \\
\text { Ginpax 40mg } \\
\text { soft gel capsule }\end{array}$ & $0.24 \mathrm{~g}$ & 21.68 & $\begin{array}{l}16.63 \pm 2.2 \\
3\end{array}$ & $\begin{array}{l}0.21 \pm 0.0 \\
5\end{array}$ & $\begin{array}{l}0.03 \pm 0.0 \\
2\end{array}$ & $\begin{array}{l}4.16 \pm 0.66 \\
5\end{array}$ & $\begin{array}{l}0.65 \pm 0.0 \\
8\end{array}$ \\
\hline Spices & & Total & $\overline{6 G}$ & $\overline{8 G}$ & $\overline{10 G}$ & $6 \mathrm{~S}$ & $\overline{10 S}$ \\
\hline
\end{tabular}




\begin{tabular}{|c|c|c|c|c|c|c|c|}
\hline & & $\begin{array}{l}\text { (Per } \\
\text { serving } \\
\text { ) }\end{array}$ & $\begin{array}{c}\text { (Per } \\
\text { serving) }\end{array}$ & $\begin{array}{c}\text { (Per } \\
\text { serving) }\end{array}$ & $\begin{array}{c}\text { (Per } \\
\text { serving) }\end{array}$ & $\begin{array}{c}\text { (Per } \\
\text { serving) }\end{array}$ & $\begin{array}{c}\text { (Per } \\
\text { serving) }\end{array}$ \\
\hline $\begin{array}{l}\text { Woolworth's } \\
\text { Ginger Spice } \\
\text { Powder }\end{array}$ & $0.212 \mathrm{~g}$ & 8.72 & $3.66 \pm 0.01$ & $\begin{array}{l}0.87 \pm 0.0 \\
0\end{array}$ & $\begin{array}{l}2.02 \pm 0.0 \\
0\end{array}$ & $1.38 \pm 0.00$ & $\begin{array}{l}0.77 \pm 0.0 \\
0\end{array}$ \\
\hline $\begin{array}{l}\text { Coles Ginger } \\
\text { Spice Powder }\end{array}$ & $0.212 \mathrm{~g}$ & 8.40 & $3.57 \pm 0.11$ & $\begin{array}{l}0.79 \pm 0.0 \\
3\end{array}$ & $\begin{array}{l}2.03 \pm 0.0 \\
6\end{array}$ & $1.31 \pm 0.04$ & $\begin{array}{l}0.71 \pm 0.0 \\
2\end{array}$ \\
\hline $\begin{array}{l}\text { Hertz Ginger } \\
\text { Spice Powder }\end{array}$ & $0.212 \mathrm{~g}$ & 0.99 & $0.57 \pm 0.08$ & $\begin{array}{l}0.09 \pm 0.0 \\
1\end{array}$ & $\begin{array}{l}0.15 \pm 0.0 \\
2\end{array}$ & $0.14 \pm 0.02$ & $\begin{array}{l}0.05 \pm 0.0 \\
1\end{array}$ \\
\hline Beverages & & $\begin{array}{l}\text { Total } \\
\text { (Per } \\
\text { serving } \\
\text { ) }\end{array}$ & $\begin{array}{c}\mathbf{6 G} \\
(\text { Per } \\
\text { serving) }\end{array}$ & $\begin{array}{c}\text { 8G } \\
\text { (Per } \\
\text { serving) }\end{array}$ & $\begin{array}{c}\text { 10G } \\
\text { (Per } \\
\text { serving) }\end{array}$ & $\begin{array}{c}6 \mathrm{~S} \\
(\mathrm{Per} \\
\text { serving) }\end{array}$ & $\begin{array}{c}\text { 10S } \\
\text { (Per } \\
\text { serving) }\end{array}$ \\
\hline $\begin{array}{l}\text { Coles Dry Ginger } \\
\text { Ale }\end{array}$ & $250 \mathrm{~mL}$ & 4.56 & $3.98 \pm 0.13$ & $\begin{array}{l}0.18 \pm 0.0 \\
1\end{array}$ & $0.03 \pm 0$ & $\begin{array}{l}0.35 \pm 0.01 \\
6\end{array}$ & $\overline{0.01 \pm 0}$ \\
\hline $\begin{array}{l}\text { Bundaberg Diet } \\
\text { Ginger Beer }\end{array}$ & $250 \mathrm{~mL}$ & 16.50 & $\begin{array}{l}13.89 \pm 1.6 \\
1\end{array}$ & $0.31 \pm 0.2$ & $\begin{array}{l}1.02 \pm 0.1 \\
2\end{array}$ & $\begin{array}{l}0.80 \pm 0.08 \\
3\end{array}$ & $\begin{array}{l}0.47 \pm 0.0 \\
6\end{array}$ \\
\hline $\begin{array}{l}\text { Saxby Dry } \\
\text { Ginger Beer }\end{array}$ & $250 \mathrm{~mL}$ & 24.23 & $\begin{array}{l}21.49 \pm 3.0 \\
5\end{array}$ & $\begin{array}{l}0.51 \pm 0.3 \\
1\end{array}$ & $\begin{array}{l}1.01 \pm 0.1 \\
3\end{array}$ & $\begin{array}{l}0.90 \pm 0.07 \\
7\end{array}$ & $\begin{array}{l}0.32 \pm 0.0 \\
3\end{array}$ \\
\hline $\begin{array}{l}\text { Cascade Ginger } \\
\text { Beer }\end{array}$ & $250 \mathrm{~mL}$ & 6.48 & $3.76 \pm 4.98$ & $\begin{array}{l}0.30 \pm 0.2 \\
4\end{array}$ & $\begin{array}{l}1.32 \pm 0.8 \\
9\end{array}$ & $0.77 \pm 0.61$ & $\begin{array}{l}0.33 \pm 0.2 \\
8\end{array}$ \\
\hline $\begin{array}{l}\text { Tiger Ginger } \\
\text { Beer }\end{array}$ & $250 \mathrm{~mL}$ & 5.09 & $4.48 \pm 0.41$ & $\begin{array}{l}0.14 \pm 0.0 \\
2\end{array}$ & $\begin{array}{l}0.18 \pm 0.0 \\
2\end{array}$ & $\begin{array}{l}0.22 \pm 0.03 \\
7\end{array}$ & $\begin{array}{l}0.07 \pm 0.0 \\
2\end{array}$ \\
\hline Confectionary & & Total & $\overline{6 G}$ & $\overline{8 G}$ & $\overline{10 G}$ & $\overline{6 S}$ & $10 \mathrm{~S}$ \\
\hline
\end{tabular}




\begin{tabular}{|c|c|c|c|c|c|c|c|}
\hline & & $\begin{array}{l}\text { (Per } \\
\text { serving }\end{array}$ & $\begin{array}{c}\text { (Per } \\
\text { serving) }\end{array}$ & $\begin{array}{c}\text { (Per } \\
\text { serving) }\end{array}$ & $\begin{array}{c}\text { (Per } \\
\text { serving) }\end{array}$ & $\begin{array}{c}\text { (Per } \\
\text { serving) }\end{array}$ & $\begin{array}{c}\text { (Per } \\
\text { serving) }\end{array}$ \\
\hline Gin Gins Candies & $12 \mathrm{~g}$ & 25.12 & $\begin{array}{l}22.85 \pm 2.2 \\
0\end{array}$ & $\begin{array}{l}0.15 \pm 0.0 \\
3\end{array}$ & $\begin{array}{l}0.65 \pm 0.0 \\
7\end{array}$ & $\begin{array}{l}1.40 \pm 0.14 \\
1\end{array}$ & $\begin{array}{l}0.08 \pm 0.0 \\
2\end{array}$ \\
\hline $\begin{array}{l}\text { Buderim } \\
\text { Crystallised } \\
\text { Ginger }\end{array}$ & $25 \mathrm{~g}$ & 5.16 & $4.74 \pm 0.25$ & $\begin{array}{l}0.16 \pm 0.0 \\
1\end{array}$ & $\begin{array}{l}0.00 \pm 0.0 \\
0\end{array}$ & $\begin{array}{l}0.19 \pm 0.00 \\
8\end{array}$ & $0.06 \pm 0$ \\
\hline $\begin{array}{l}\text { Buderim Ginger } \\
\text { bears }\end{array}$ & $48 \mathrm{~g}$ & 11.88 & $\begin{array}{l}10.38 \pm 0.8 \\
4\end{array}$ & $\begin{array}{l}0.58 \pm 0.0 \\
2\end{array}$ & $\begin{array}{l}0.45 \pm 0.0 \\
2\end{array}$ & $\begin{array}{l}0.43 \pm 0.02 \\
5\end{array}$ & $0.04 \pm 0$ \\
\hline $\begin{array}{l}\text { Arnotts } \\
\text { GingerNut } \\
\text { Biscuits }\end{array}$ & 1 biscuit & 2.14 & $1.28 \pm 0.03$ & $\begin{array}{l}0.14 \pm 0.0 \\
0\end{array}$ & $\begin{array}{l}0.29 \pm 0.0 \\
0\end{array}$ & $0.24 \pm 0$ & $\begin{array}{l}0.19 \pm 0.0 \\
3\end{array}$ \\
\hline Teas & & $\begin{array}{l}\text { Total } \\
\text { (Per } \\
\text { serving }\end{array}$ & $\begin{array}{c}\text { 6G } \\
\text { (Per } \\
\text { serving) }\end{array}$ & $\begin{array}{c}\text { 8G } \\
\text { (Per } \\
\text { serving) }\end{array}$ & $\begin{array}{c}\text { 10G } \\
\text { (Per } \\
\text { serving) }\end{array}$ & $\begin{array}{c}\text { 6S } \\
(\text { Per } \\
\text { serving) }\end{array}$ & $\begin{array}{c}\text { 10S } \\
\text { (Per } \\
\text { serving) }\end{array}$ \\
\hline $\begin{array}{l}\text { Twinings Ginger } \\
\text { \& Lemon Tea }\end{array}$ & 1 teabag & 0.15 & $0.11 \pm 0.01$ & $\begin{array}{l}0.01 \pm 0.0 \\
0\end{array}$ & $\begin{array}{l}0.01 \pm 0.0 \\
0\end{array}$ & $0.01 \pm 0.00$ & $\begin{array}{l}0.01 \pm 0.0 \\
0\end{array}$ \\
\hline $\begin{array}{l}\text { Nerada Ginger \& } \\
\text { Lemon Tea }\end{array}$ & 1 teabag & 0.04 & $0.04 \pm 0.00$ & $\begin{array}{l}0.00 \pm 0.0 \\
0\end{array}$ & $\begin{array}{l}0.00 \pm 0.0 \\
0\end{array}$ & $0.00 \pm 0.00$ & $\begin{array}{l}0.00 \pm 0.0 \\
0\end{array}$ \\
\hline
\end{tabular}

*6G=[6]-gingerol, 8G =[8]-gingerol, 6S=[6]-shogaol, 10G=[10]-gingerol, 10S=[10]-shogaol. 